\title{
Is Sugammadex a Reliable Option for Extubation Conditions in Patients Without Neuromuscular Monitorisation Guidance? A Randomised Clinical Study
}

\author{
Nöromusküler Monitorizasyon Rehberliğinin Olmadığı Hastalarda, Sugammadex \\ Ekstübasyon için Güvenilir bir Seçenek Midir? Randomize Klinik Çalışma
}

(1) Çiğdem Yıldırım Güçlü, (1) Zekeriyya Alanoğlu, (1) Başak Ceyda Meço, (D) Menekşe Özçelik, (D) Sanem Çakar Turhan, (D) Barış Adaklı, (D) Neslihan Alkış

Ankara University Faculty of Medicine, Department of Anesthesiology and Intensive Care Unit, Ankara, Turkey

\section{Abstract}

Objectives: In patients undergoing septorhinoplasty, anesthesia and management of postoperative care may be challenging, especially at extubation, due to nasal packing. Maintaining a patent airway is a critical issue in these patients. In this study, extubation characteristics of sugammadex in the absence of neuromuscular monitorization were evaluated.

Materials and Methods: In this randomized, prospective trial, 90 patients who underwent septorhinoplasty were allocated to groups to reversal with either neostigmine or sugammadex, with or without neuromuscular monitorization guidance for extubation. The induction and maintenance were standardized for all groups and groups were differed according to the reversal agent and presence of neuromuscular monitorization. The extubation conditions were recorded. Extubation time and time spent in postanesthesia care unit were also recorded.Adverse events such as throat pain, cough, straining, or laryngospasm were recorded in the operating room and until discharge from the post anesthesia care unit. Nasal bleeding and change of packing were recorded.

Results: The mean extubation time (time from the administration of reversal agent to extubation) and post anesthesia care unit stay time [Group 1: $20.5 \pm 4.1$ minute (min), Group 2: $21.3 \pm 7.3 \mathrm{~min}$, Group 3: 12 12.2 $\pm 2.9 \mathrm{~min}$, Group 4: $12.7 \pm 2.5 \mathrm{~min}$ ] ( $\mathrm{p}=0.001)$ were significantly shorter in the sugammadex groups than in the neostigmine groups. Number of patients in the sugammadex groups required less mask ventilation compared to the neostigmine groups, regardless of the neuromuscular monitorization.

Conclusion: Sugammadex may provide favorable extubation conditions than neostigmine regardless of objective neuromuscular monitorization. Key Words: Extubation, Neostigmine, Sugammadex

\section{Öz}

Amaç: Septorinoplasti uygulanan hastalarda, anestezi ve postoperatif bakım yönetimi, özellikle de ekstübasyonda nazal tampon nedeniyle zor olabilir. Bu hastalarda patent hava yolunun sağlanması kritik bir konudur. Bu çalışmada, nöromüsküler monitörizasyon yokluğunda, sugammadeksin ekstübasyon karakteristikleri değerlendirildi.

Gereç ve Yöntem: Bu randomize, prospektif çalışmada, septorinoplasti yapılan 90 hasta, ekstübasyon için nöromüsküler monitörizasyon rehberliğinde veya olmaksızın, neostigmin veya sugammadeks ile geri döndürme için gruplara ayrıldı. Indüksiyon ve idame, tüm gruplar için standardizeydi ve gruplar geri döndürücü ajan ve nöromüsküler monitörizasyon varlığına göre farklılık gösterdi. Ekstübasyon koşulları kaydedildi. Ekstübasyon süresi ve anestezi sonrası bakım ünitesinde geçirilen süre de kaydedildi. Boğaz ağrısı, öksürük, ıkınma veya laringospazm gibi istenmeyen olaylar ameliyathanede ve anestezi sonrası bakım ünitesinden taburcu edilene kadar kaydedildi. Burun kanaması ve tampon değişikliği kaydedildi.

Address for Correspondence/Yazışma Adresi: Çiğdem Yııdırım Güçlü,

Ankara University Faculty of Medicine, Department of Anesthesiology and Intensive Care Unit, Ankara, Turkey

Phone: +90 5324576648 E-mail: drcigdemyldrm@yahoo.com.tr ORCID ID: orcid.org/0000-0002-8416-3418

Received/Geliş Tarihi: 25.08.2020 Accepted/Kabul Tarihi: 01.11.2020

๑Copyright 2021 Ankara University Faculty of Medicine

Journal of Ankara University Faculty of Medicine is published by Galenos Publishing House.

All content are under CC BY-NC-ND license. 
Bulgular: Ortalama ekstübasyon süresi (reversal ajan uygulamasından ekstübasyona kadar geçen süre) ve anestezi sonrası bakım ünitesinde kalış süresi (Grup 1: 20,5 $\pm 4,1$ dakika (dk), Grup 2: 21,3 $\pm 7,3$ dk, Grup 3: 12 12,2 $\pm 2,9$ dk, Grup 4: 12,7 $\pm 2,5$ dakika) ( $p=0,001$ ) sugammadeks gruplarında, neostigmin gruplarından anlamlı olarak daha kısaydı. Nöromüsküler monitörizasyondan bağımsız olarak, sugammadeks gruplarında neostigmin gruplarına kıyasla daha az hastaya maske ventilasyonu gerekti.

Sonuç: Sugammadeks, objektif nöromüsküler monitörizasyondan bağımsız olarak, neostigminden daha uygun ekstübasyon koşulları sağlayabilir. Anahtar Kelimeler: Ekstübasyon, Neostigmine, Sugammadeks

\section{Introduction}

In patients undergoing septorhinoplasty, anesthesia and postoperative airway managementcan be challenging, especially during extubation period, related to upper airway obstruction and difficulty in mask ventilation due to nasal packing (1). Complications after septorhinoplasty may include but not limited to laryngospasm, bronchospasm, and desaturation due to secretions and blood and nasal packing. Adequate reversal of neuromuscular blockade at the end of surgery increases patient safety, and patient comfort, and also decreases the time spent in the operating room and post-anesthesia care unit (2).

Septorhinoplasty operations requires deep neuromuscular block during anesthesia management to avoid straining. However, deep neuromuscular block during anesthesia management may prolong the recovery time. Mask ventilation after septoplasty may lead dislocation of nasal splint that may compromise the surgical and cosmetic outcome. Any intervention avoiding mask ventilation may positively impact the surgical outcome and better recovery profile. Neuromuscular monitorisation is needed for objective assessment level of muscular block. Even though neuromuscular monitorisation should be one of the standart monitorisation for general anesthesia, this may not be available in all anesthesia suits. In the absence of objective neuromuscular monitorisation, decision for extubation is maintained with the guidance of clinical parameters and subjective decision making of the anesthesiologist.

Sugammadex is an antagonist of rocuronium and vecuronium. Sugammadex achieves rapid reversal of muscle relaxation. According to the literature sugammadex achieves more reliable, complete, and rapid reversal of neuromuscular blockade than traditional reversal agents (3-6).

The aim of the present study was to compare sugammadex versus neostigmine for reversal of rocuroniuminduced neuromuscular blockade with or without neuromuscular monitorisation guidance in patients undergoing septorhinoplasty. We hypothesize that sugammadex may necessitates less mask ventilation compared to traditional reversal with neostigmine.
Moreover, the use of sugammadex may decrease the impact of objective monitorisation on the recovery profile and provide equal and favorable recovery characteristics even in patients without objective monitorisation.

\section{Materials}

This study was approved by the University's Institutional Ethical Board (IRB: 17393) and written informed consent was obtained from all subjects participating in the trial. The trial was registered prior to patient enrollment at clinicaltrials.gov (NCT02026999) (Date of registration: 22/12/2013).

There were 90 patients who had elective septorhinoplasty were enrolled in this randomized, prospective study. The inclusion criteria were (1) American Society of Anesthesiologists physical status I to III; (2) age>18 years; and (3) scheduled septorhinoplasty under general anesthesia. Patients with (1) history of any allergic reaction to muscle relaxants or other medications; (2) previous malignant hyperthermia; (3) interfere with neuromuscular disease and asthma (4) and current use of drugs that may neuromuscular blockers, pregnancy, or breastfeeding (5) high difficult airway risk scores and patients who had surgery lasting more than 3 hours were excluded. All patients gave written signed informed consent for their inclusion to the study.

Patients were randomly assigned into 4 different groups via sealed envelope technique to receive either sugammadex or neostigmine as a reversal agent with or without objective neuromuscular monitorisation. All patients were medicated with midazolam $\left(0.01 \mathrm{mg} \cdot \mathrm{kg}^{-1}\right.$ at 30 minutes before induction of anesthesia). After the patient arrived in the operating room, routine monitors were applied to record heart rate, mean arterial blood pressure, and oxygen saturation values. After the pre-oxygenation, anesthesia was induced with thiopental (5 mg. $\left.\mathrm{kg}^{-1}\right)$, rocuronium $\left(0.6 \mathrm{mg} \cdot \mathrm{kg}^{-1}\right)$, and remifentanil (0.1 $\left.\mu . \mathrm{kg}^{-1}\right)$. Anesthesia was maintained with desflurane (4\%-6\% end-tidal-level) in a mixture of oxygen and nitrous oxide. Ventilation was controlled to maintain the end-tidal carbon dioxide 30 to $35 \mathrm{mmHg}$. All patients received tramadol (1 $\mathrm{mg} \cdot \mathrm{kg}^{-1}$ ) for treatment of pain at the end of the surgery. 
Neuromuscular function was monitored at the adductor pollicis muscle via TOF-Watch SX Acceleromyograph, Organon Ireland Ltd., Dublin, Irelands.

The train of four tracing was stabilized after induction of anesthesia by giving a standardized sequence of repetitive train of fourstimulation (1minute), $50-\mathrm{Hz}$ tetanic stimulation (5 s), and another repetitive train of four stimulation (3-4 minutes) as previously described (7-9). Central body temperature was maintained at over $36^{\circ} \mathrm{C}$.

After induction of anesthesia, additional doses of rocuronium $\left(0.15 \mathrm{mg} \cdot \mathrm{kg}^{-1}\right)$ were given when the second twitch (T2) appeared in the train-of-four monitor. In the nonmonitorized groups additional doses of $0.1 \mathrm{mg} \cdot \mathrm{kg}^{-1}$ Rocuronium was administered every 30 minutes. As the surgery finished and the inhalational agent end tidal concentration was less than 0.2 MAC, reversal of neuromuscular blockade was performed according to the: Group 1 (neostigmine, without guidance of objective monitorisation): neostigmine (0.04 $\left.\mathrm{mg} . \mathrm{kg}^{-1}\right)$ and atropine $(0.5 \mathrm{mg})$ were given when first breathing effort detected; Group 2 (neostigmine, with guidance of monitorisation): neostigmine $\left(0.04 \mathrm{mg} \cdot \mathrm{kg}^{-1}\right)$ and atropine $(0.5$ $\mathrm{mg}$ ) were given by the second twitch of the train of four monitor; Group 3 (sugammadex, without guidance of monitorisation): sugammadex (2 mg. $\left.\mathrm{kg}^{-1}\right)$ was given when the first breathing effort detected; and Group 4 (sugammadex with guidance of monitorisation): sugammadex $\left(2 \mathrm{mg} \cdot \mathrm{kg}^{-1}\right)$ was given by the second twitch of the train of four monitor.

Hemodynamic parameters were recorded until 20 minutes after the end of surgery. End of surgery is defined as the last suture performed and the end tidal Desfluran concentration is equal or less than aged and weight adjust MAC of 0.2 . The extubation time, defined as the time between the administration of reversal agent (sugammadex or neostigmine) and extubation was recorded. Patients in the objective monitorisation groups were extubated as the TOF ratio was greater or equal to 0.9. Patients in no monitorisation groups were extubated as they were responsive to the simple comments. Immediately after extubation all patients were evaluated for the need of mask ventilation and mask ventilation is initiated in patient who had compromised airway, upper airway obstruction and declining peripheral oxygen saturation. The mask ventilation difficulty score $(1$, easy; 2 , with effort; 3, with 2 hands), head lifting times the need for mask ventilation were evaluated. Adverse events such as throat pain, cough, straining, or laryngospasm were recorded in the operating room and until discharge from the post anesthesia care unit (PACU). Nasal bleeding, and change of packing were recorded.

The patients in neuromuscular monitorisation groups were transferred to the PACU as they had TOF ratio $\geq 0.9$ and the patients in no monitor groups were transferred to PACU when they were able to answer simple questions, with a patent airway, exchanging well and having stable 02 saturations. The patients were discharged from PACU to recovery area as the modified aldrete score reached $>8$. The time spent in PACU was also recorded.

A preliminary data collection was done to define the mean and standard deviation of extubation time for sugammadex and neostigmine with objective monitorisation. Clinical significance was considered as at least a $20 \%$ difference in extubation time between neostigmine and sugammadex groups. A power analysis was initiated and a number of at least 20 patient per group was calculated with an alfa error of 0.05 and beta error of 0.2 (power $80 \%$ ). Data analysis was performed with statistical software (SPSS for Windows, version 15, SPSS Inc., USA). Shapiro-Wilks test used as normality test. Descriptive statistics that had normal distribution were expressed as mean \pm standard deviation. One-Way ANOVA was used to evaluate the differences between groups. Nominal variables were evaluated with Pearson $x^{2}$ test (chi-square test) or Fisher exact test. Statistical significance was defined by $p<0.05$.

\section{Results}

Ninety patients were consented to participate in the study, 2 patients were excluded because of technical problems with TOF monitorisation. The clinical characteristics of four groups were presented in Table 1.

Table 1: Clinical characteristics of patients undergoing septoplasty and reversal of neuromuscular blockade and extubation time

\begin{tabular}{|c|c|c|c|c|c|}
\hline Characteristic & Group 1 & Group 2 & Group 3 & Group 4 & $\mathbf{p} \leq^{+}$ \\
\hline Number of patients & 22 & 22 & 22 & 22 & \\
\hline Age (y) & $29 \pm 10$ & $27 \pm 9$ & $30 \pm 10$ & $24 \pm 10$ & 0.214 \\
\hline Height $(\mathrm{cm})$ & $166 \pm 7$ & $166 \pm 8$ & $170 \pm 8$ & $169 \pm 9$ & 0.365 \\
\hline Extubation time $(\mathrm{sec})^{\neq}$ & $480 \pm 240$ & $540 \pm 180$ & $420 \pm 240$ & $360 \pm 180$ & 0.05 \\
\hline
\end{tabular}

(Group 1: Neostigmine, without neuromuscular monitorisation guidance, Group 2: Neostigmine, with neuromuscular monitorisation guidance, Group 3: Sugammadex, without neuromuscular monitorisation guidance, Group 4: Sugammadex, with neuromuscular monitorisation guidance.

Extubation time: The time interval between extubation and end of surgery. $\mathrm{N}=90$ patients. Data reported as mean $\pm \mathrm{SD}$ or number (\%). ${ }^{+}$

SD: Standard deviation 
Mean extubation time was significantly shorter with sugammadex groups compared to neostigmine groups regardless of neuromuscular monitorisation (Table 1). Mask ventilation difficulty scores revealed that mask ventilation was easier in sugammadex group (Table 2). Only 1 of all patients in the study (group 4) received an additional dose of sugammadex because of inadequate reversal of neuromuscular blockade.

Patients receiving sugammadex had significantly shorter mean PACU stay time than patients who had neostigmine (Group 1: 20.5 \pm 4.1 minute, group 2:21.3 \pm 7.3 minute, group 3: 12.2 \pm 2.9 minute, group 4:12.7 \pm 2.5 minute) ( $p=0.001$ ) (Table 2 ).

The most frequent complications were straining, cough, and nasal bleeding (Table 3). Only one patient in-group 1 had laryngospasm, received steroid for treatment besides having positive pressure ventilation.

In groups receiving neostigmine, objective monitorisation has no impact on extubation time and PACU stay time ( $p=0.18$ and 0.57 respectively). In groups receiving sugammadex (group 3 and 4), extubation time and PACU stay results were also similar ( $p=0.68$ and 0.75 respectively). The mask ventilation need was significantly lower in groups received. Sugammadex as compared to neostigmine groups ( $p=0.03$ ) (Table 2).

\section{Discussion}

The results of this study reveals that sugammadex may considered as the preferred neuromuscular reversal agent for patients who have postoperative nasal packing which obstructs upper airway as the mean extubation time was shorter, mask ventilation was less frequently rated as difficult, the incidence of mask ventilation need was lower and post-anesthesia care unit stay was shorter with sugammadex used groups.

In order to improve patient safety and complete reversal of neuromuscular blockade should be the upmost priority. Incomplete reversal of neuromuscular blockade or residual blockade may cause airway obstruction, postoperative pulmonary complications, and other major morbidity (10-13).

Difficult mask ventilation due to cast on operated nose is a common problem after septorhinoplasty and may be caused by excessive edema of face and both nostrils, occlusion of upper airway or an inadequate seal between the face and mask (14). Functioning upper airway reflexes are crucial to maintain a patent airway after septorhinoplasty. The present results confirm previous findings of studies that sugammadex may provide better reversal of neuromuscular blockade and extubation conditions than neostigmine with shorter extubation time, less mask ventilation need, less mask difficulty and shorter postanesthesia stay (15-19).

During septorhinoplasty operations, deep neuromuscular block should be maintained through the surgery. Besides, due to the plaster dressing difficult mask ventilation becomes an important issue. In ideal settings, at the end of the surgery adequate recovery is essential and minimal mask ventilation should be performed to ensure minimal intervention to the operational nose. Difficult mask ventilation and need for mask ventilation was found significantly less frequent in sugammadex used groups than neostigmine used groups in this study.

Studies for sugammadex were mostly focused on time spent for extubation, and they conclude that sugammadex provided

\begin{tabular}{|c|c|c|c|c|c|}
\hline Characteristic & Group1 & Group 2 & Group 3 & Group 4 & $\mathbf{p} \leq^{+}$ \\
\hline Mask ventilation needed (n of patients) & $18(81,8 \%)$ & $18(81,8 \%)$ & $11(50 \%)$ & $12(54,5 \%)$ & 0.03 \\
\hline Postanesthesia care unit stay (min) & $20,5 \pm 4,1$ & $21,3 \pm 7,3$ & $12,2 \pm 2,9$ & $12,7 \pm 2,5$ & 0.001 \\
\hline
\end{tabular}

Mask ventilation difficulty refers to mask ventilation score $>2$. Data reported as mean $\pm S D$ or number $(\%) p \leq 0.03$. Difference between groups 2 and 4 , ( $p \leq 0.01)$.

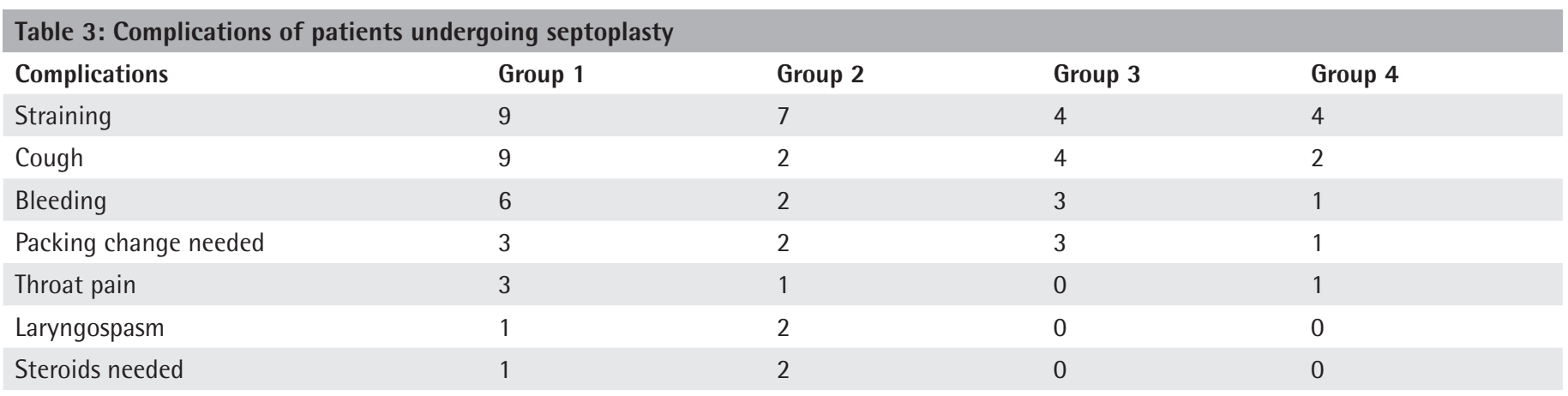

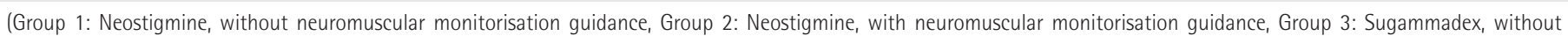
neuromuscular monitorisation guidance, Group 4: Sugammadex, with neuromuscular monitorisation guidance. Data reported as number of patients) 
significantly faster recovery than neostigmine, that is consistent with our result (20).

Complications associated with this type of surgery may cause upper airway obstruction including nasal packing and bleeding. In this study; the number of patients who had an event such as cough, bleeding, laryngospasm, and throat pain was higher in the neostigmine than sugammadex groups.

Laryngospasm did not occur in any patient who had sugammadex, but laryngospasm occurred and required treatment (positive pressure ventilation, steroid iv or inhaler) in 3 patients who had neostigmine.

Neuromuscular monitorisation is essential in most of the anesthesia settings. It may provide a safer and objective anesthesia management. However, it may not be available in all anesthesia workstations. Septorhinoplasty operations requires deep block during anesthesia to avoid straining.

Keeping the patient at deep block level during anesthesia may prolong the recovery time. The hypothesis of our study was to evaluate the effectiveness of sugammadex even without the guidance of neuromuscular monitorisation. Our results revealed that the use of sugammadex even with no objective monitorisation provides similar outcome (extubation time and clinical parameters) with objective monitorisation patients. Timing of extubation, which is an important determiner of need for objective monitorisation, did not differ between monitorized and non-monitorized groups.

However this is not a claim for not using neuromuscular monitorisation routinely, but in the absence of objective monitorisation undergoing septorhinoplasty operations. Even it has been concluded that there is still a risk of sugammadex may offer safe extubation parameters in patients 1.7\%-9.4\% residual block at PACU in the absence of monitorisation, our results showed no difference between groups receiving sugammadex with or without monitorisation (18).

\section{Study Limitations}

The limitation of the study may be; discharging patients from PACU without TOF monitorisation, but as this may be painful for the patient, we avoided doing it.

\section{Conclusion}

The present results suggest that sugammadex may provide more rapid and better recovery from neuromuscular blockade than neostigmine in patients undergoing septoplasty even without neuromuscular monitorisation guidance. The better recovery with sugammadex may be attributed to easier mask ventilation, fewer complications, and shorter PACU stay than with neostigmine. Sugammadex $2 \mathrm{mg} \cdot \mathrm{kg}-1$ provides similar results without monitorisation guidance like objective monitorisation does. Different doses of sugammadex should be studied in the future studies.

\section{Ethics}

Ethics Committee Approval: This study was approved by the Ankara University's Institutional Ethical Board (IRB: 17393).

Informed Consent: Written informed consent was obtained from all subjects participating in the trial.

Peer-reviewed: Externally peer-reviewed.

\section{Authorship Contributions}

Surgical and Medical Practices: B.A., Ç.Y.G., Concept: Ç.Y.G., Z.A., Design: Ç.Y.G., Z.A., Data Collection or Processing: S.Ç.T., M.Ö., Analysis or Interpretation: Ç.Y.G., B.C.M., Literature Search: B.A., N.A., Writing: Ç.Y.G., Z.A.

Conflict of Interest: No conflict of interest was declared by the authors.

Financial Disclosure: The authors declared that this study has received no financial support.

\section{References}

1. Geldner $G$, Niskanen $M$, Laurila $P$, et al. A randomised controlled trial comparing sugammadex and neostigmine at different depths of neuromuscular blockade in patients undergoing laparoscopic surgery. Anaesthesia. 2012;67:991-998.

2. Jones RK, Caldwell JE, Brull SJ, et al. Reversal of profound rocuroniuminduced blockade with sugammadex: a randomized comparison with neostigmine. Anesthesiology. 2008;109:816-824.

3. Blobner M, Eriksson LI, Scholz J, et al. Reversal of rocuronium-induced neuromuscular blockade with sugammadex compared with neostigmine during sevoflurane anaesthesia: results of a randomised, controlled trial. Eur J Anaesthesiol. 2010;27:874-881.

4. Khuenl-Brady KS, Wattwil M, Vanacker BF, et al. Sugammadex provides faster reversal of vecuronium-induced neuromuscular blockade compared with neostigmine: a multicenter, randomized, controlled trial. Anesth Analg. 2010;110:64-73.

5. Naguib M. Sugammadex: another milestone in clinical neuromuscular pharmacology. Anesth Analg. 2007;104:575-581.

6. Arain SR, Kern S, Ficke DJ, et al. Variability of duration of action of neuromuscular-blocking drugs in elderly patients. Acta Anaesthesiol Scand. 2005;49:312-315.

7. Suy K, Morias K, Cammu G, et al. Effective reversal of moderate rocuroniumor vecuronium-induced neuromuscular block with sugammadex, a selective relaxant binding agent. Anesthesiology. 2007;106:283-288.

8. Vanacker BF, Vermeyen KM, Struys MM, et al. Reversal of rocuroniuminduced neuromuscular block with the novel drug sugammadex is equally effective under maintenance anesthesia with propofol or sevoflurane. Anesth Analg. 2007;104:563-568.

9. Murphy GS. Residual neuromuscular blockade: incidence, assessment, and relevance in the postoperative period. Minerva Anestesiol. 2006;72:97-109.

10. Debaene B, Plaud B, Dilly MP, et al. Residual paralysis in the PACU after a single intubating dose of nondepolarizing muscle relaxant with an intermediate duration of action. Anesthesiology. 2003;98:1042-1048.

11. Shorten GD. Postoperative residual curarisation: incidence, aetiology and associated morbidity. Anaesth Intensive Care. 1993;21:782-789.

12. Shah PN, Sundaram V. Incidence and predictors of difficult mask ventilation and intubation. J Anaesthesiol Clin Pharmacol. 2012;28:451-455. 
13. Ramachandran SK, Kheterpal S. Difficult mask ventilation: does it matter? Anaesthesia. 2011;66:40-44.

14. Sacan 0 , White PF, Tufanogullari $B$, et al. Sugammadex reversal of rocuronium-induced neuromuscular blockade: a comparison with neostigmine-glycopyrrolate and edrophonium-atropine. Anesth Analg. 2007;104:569-574.

15. Flockton EA, Mastronardi $P$, Hunter JM, et al. Reversal of rocuroniuminduced neuromuscular block with sugammadex is faster than reversal of cisatracurium-induced block with neostigmine. Br J Anaesth. 2008;100:622630.

16. Paton $F$, Paulden $M$, Chambers $D$, et al. Sugammadex compared with neostigmine/glycopyrrolate for routine reversal of neuromuscular block: a systematic review and economic evaluation. Br J Anaesth. 2010;105:558567.
17. Schaller SJ, Fink $H_{1}$ Ulm K, et al. Sugammadex and neostigmine dose-finding study for reversal of shallow residual neuromuscular block. Anesthesiology. 2010;113:1054-1060.

18. Kotake $Y$, Ochiai R, Suzuki T, et al. Reversal with sugammadex in the absence of monitoring did not preclude residual neuromuscular block. Anesth Analg. 2013;117:345-351.

19. Eikermann $M$, Zaremba $S$, Malhotra $A$, et al. Neostigmine but not sugammadex impairs upper airway dilator muscle activity and breathing. $\mathrm{Br}$ J Anaesth. 2008;101:344-349.

20. Della Rocca G, Pompei L, Pagan DE Paganis C, et al. Reversal of rocuronium induced neuromuscular block with sugammadex or neostigmine: a large observational study. Acta Anaesthesiol Scand. 2013;57:1138-1145. 